\title{
Using Habits of Mind, Intelligent Behaviors, and Educational Theories to Create a Conceptual Framework for Developing Effective Teaching Dispositions
}

Journal of Teacher Education 2019, Vol. 70(2) 169-183 (C) 2017 American Association of Colleges for Teacher Education Article reuse guidelines: sagepub.com/journals-permissions DOI: $10.1177 / 0022487$ I I7736024 journals.sagepub.com/home/jte

(S)AGE

\author{
Servet Altan', Jennie F. Lane', and Erskine Dottin ${ }^{2}$
}

\begin{abstract}
Despite the heated debates about dispositions in teacher education, most accrediting agencies continue to put dispositions among their priorities. The authors of the current article concur with the value of using Dewey to understand how habits can be clustered to better understand intelligent teaching dispositions. But, can we extend Dewey's epistemology to learning theories in a manner that informs the making of teaching conduct more intelligent? To address this question, the authors applied qualitative content analysis to review the literature. Through a deductive approach, dispositions as Habits of Mind were related to educational theories using intelligent behaviors as the common denominator. The conclusion is that dispositions can be clustered around Habits of Mind that are related directly to educational learning theories vis-à-vis thoughtfulness, and to learning theories that support learning or mindfulness. Grounding dispositions as habits of mind in selected educational theories may guide and support the professional development of teaching dispositions.
\end{abstract}

\section{Keywords}

teacher education preparation, standards, teacher characteristics, teachers' disposition, habits of mind

In teacher preparation institutions today, in addition to learning knowledge and skills needed to educate children, future teachers are being introduced to new ways of thinking and behaving. One of these ways, referred to as dispositions in this article, has become a topic of interest for programs and researchers in teacher education.

In the United States, accrediting bodies for teacher preparation including the Interstate New Teacher Assessment and Support Consortium (INTASC; 1992) and the National Council for Accreditation of Teacher Education (NCATE; 2008), which merged with the Teacher Education Accreditation Council (TEAC) to become the Council for the Accreditation of Educator Preparation (CAEP; 2013), have given great significance to teachers' dispositions. The glossary of the CAEP, which is now the sole accrediting body for educator preparation providers in the United States since July 1 2013, defines dispositions as "the values, commitments, and professional ethics that influence behaviors towards students, families, colleagues, and communities that affect student learning, motivation, and development as well as the educator's own professional growth" (http://caepnet. org/glossary). CAEP (2013) also noted that professional education departments may add their own dispositions in addition to fairness and the belief that all students can learn. The term "dispositions" has not only emerged in the lexicon of the U.S. teacher education authorities, but also it has started an international discussion about focusing more on dispositions to meet the needs of today's learners. The Council of European Union for Teacher Education includes dispositions among its priorities for teacher achievement; however, they acknowledged disposition as a construct is challenging to define and assess (Caena, 2011).

Consequently, teacher education programs have started to put dispositions among its priorities for teacher achievement. However, what may have started with best intentions to encourage teachers to develop and exhibit positive attitudes and conduct toward student education has splintered into debates about values, morals, and proper conduct in schools. The lack of common grounding for dispositions in teacher education has led to a heated debate across and among teacher education institutions and scholars (Borko, Liston, \& Whitcomb, 2007; Ruitenberg, 2011). Complicating matters further is that English, with its penchant for synonyms, has

\footnotetext{
'Bilkent University, Ankara, Turkey

${ }^{2}$ Florida International University, Miami, USA

Corresponding Author:

Servet Altan, Graduate School of Education, Bilkent University, 06800 Çankaya, Ankara, Turkey.

Email: serveta@bilkent.edu.tr
} 
many different words similar to dispositions - each of which may have nuanced and more blatant interpretations based on the perspectives and epistemology of the educator. Due to the lack of clarity about the term, dispositions in teacher education have been used interchangeably with values, beliefs, and professional commitments and actions. Other terms that have been used by scholars when investigating dispositions include identities, self, habits, manners, inclinations, mindset, tendency, propensity, predilection, characteristics, and values (Claxton \& Carr, 2004; Costa \& Kallick, 2014; Serdyukov \& Ferguson, 2011). Given the abstract nature of dispositions, it is not surprising that myriad interpretations have been offered in the literature to help educational institutions prepare teachers to exhibit effective dispositions. Following are some definitions that have been used to describe dispositions:

- An attributed characteristic of a teacher, one that summarizes the trend of a teacher's actions in particular contexts (Katz \& Raths, 1985, p. 306).

- Acquired patterns of behavior that are under one's control and will as opposed to being automatically activated. Dispositions are overarching sets of behaviors, not just single behaviors (Ritchhart, 2002, p. 31).

- Individual's tendencies to act in a particular manner (Borko et al., 2007, p. 361).

- Part of a set of larger abilities that include knowledge, skill, values, beliefs, and commitments (Diez, 2007, p. 394).

In addition to the tension over the definition of dispositions in teacher education, there are also discussions over the malleability of dispositions and whether dispositions can be linked to observable traits (Borko et al., 2007; Diez, 2007; Nelsen, 2015). Nelsen (2015) views the tension over disposition in teacher education from three lenses: the question of whether dispositions are revisable or immutable, whether dispositions are responsive to educative experiences, or whether there is a relationship between disposition and behaviors. If dispositions are viewed as immutable traits, institutions may tend to filter teacher candidates and focus on the ends rather than the means.

Given the increasing worldwide interest in fostering dispositions in teacher education, the need to provide professional educators with a sound construct for understanding dispositions becomes even more pronounced. The authors of the current article address this need by offering a conceptual framework to better identify and promote constructive ways of thinking about dispositions as habits of mind in teacher education. This conceptual framework may help institutions operationalize the most recent INTASC (2013) iteration that critical dispositions are habits of professional action and moral commitments that underlie a teacher's performance.

In part, this article is a follow-up to the recommendation by Nelsen (2015) that we "consider dispositions in teacher education to be clusters of habits" (p. 2, emphasis in the original). We agreed with the argument of having these clusters, but wondered which habits should be clustered and why? We answered this question by exploring how Costa and Kallick's model of Habits of Mind can be used to cluster habits around educational theories and to better understand constructive ways of thinking and behaving as dispositions. We suggest that their list of Habits of Mind (dispositions), based on intelligent behaviors, can assist teacher educators and researchers to explore, cultivate, and assess dispositions.

The content analysis of the literature presented in this article identifies well-researched and accepted explanations for ways of thinking and behaving that strengthen theoretical underpinnings for Habits of Mind as proposed by Costa and Kallick (2000). To start this investigation, we reviewed the nature of Deweyan habit and under which conditions Dewey used habit interchangeably with dispositions.

\section{Deweyan Habit and Disposition}

Many scholars (Costa \& Kallick, 2014; Dottin, 2009; Dottin \& Sockett, 2006; Nelsen, 2015; Ritchhart, 2001; Thornton, 2006) have turned to Dewey's concept of habit to investigate the effective use of the term dispositions in teacher education. In his early work, Dewey (1922) refers to disposition as the underlying motivator and organizer for intelligent behaviors. He used disposition and habit interchangeably except when habit is used in its ordinary sense where it may sound like a mindless and automatic response.

Habits grow from our experiences and "every experience is a moving force" (Dewey, 1938, p. 38). However, not all our experiences are educative, and Dewey suggests that the goal of education is to focus on educative experiences that are likely to help learners develop effective habits. Dewey (1922) considers these effective habits as intelligent habits that retain their plasticity, and that are revisable.

Dottin (2009) also argues "that dispositions have a cognitive dimension, and as such there is a relation of dispositions as habits of mind and intelligent professional conduct" (p. 87). He reminds the reader of Dewey's endorsement of mindful and thoughtful habits for intelligent behaviors. In his discussion of several educational perspectives on the qualities of intelligent professional conduct, he includes Costa and Kallick's (2000) Habits of Mind.

\section{Habits of Mind and Intelligent Behaviors}

The mind is often mentioned in definitions of dispositions; the issue is how to know what the mind is thinking. It is no surprise then that from Dewey forward, scholars have used the term "habits of mind" in their analysis of dispositions. As with dispositions, habits of mind have also been defined and described in various ways. The following definitions of dispositions include the term "habits of mind": 
- A disposition is a pattern of behavior exhibited frequently in the absence of coercion constituting a habit of mind under some conscious and voluntary control intentional to broad goals. Dispositions should not be confused with mindless habits such as stopping at red light (Katz, 1993, p. 16).

- Dispositions are habits of mind including both cognitive and affective attributes that filter one's knowledge, skills, and beliefs and impact the action one takes in classroom or professional setting. They are manifested within relationships as meaning making occurs with others and they are evidences through interactions in the form of discourse (Thornton, 2006, p. 62).

In addition to using habits of minds and behaviors to define dispositions, researchers have attempted to organize and provide hierarchies for dispositions (Ennis, 1996; Facione, Sanchez, Facione, \& Gainen, 1995; Marzano, 1992; Paul, 1990; Perkins, Jay, \& Tishman, 1993). For the purpose of this article, we focus on Costa and Kallick's (2000) list of dispositions as 16 Habits of Mind. In this article, when we are referring to their model, we will capitalize Habits of Mind, and when discussing the concept in general, lowercase letters will be used.

Their Habits of Mind are based on intelligent behaviors that constitute a subset of thinking dispositions. Dewey (1922) refers to disposition as the underlying motivator and organizer for intelligent behaviors. Costa and Kallick explain that they developed their model of Habits of Mind from studies of successful, efficient thinkers from many walks of life (Costa, 2001). Another reason for choosing this model is that it includes dispositions that are beyond thinking, such as Responding With Wonderment and Awe and Finding Humor. Costa and Kallick's (2000) 16 Habits of Mind include the following:

- Applying Past Knowledge to Novel Situations

- Creating, Imagining, and Innovating

- Finding Humor

- Gathering Data Through All Senses

- Listening With Understanding and Empathy

- Managing Impulsivity

- Metacognition (Thinking About Thinking)

- Persisting

- Questioning and Problem Posing

- Remaining Open to Continuous Learning

- Responding With Wonderment and Awe

- Striving for Accuracy and Precision

- Taking Responsible Risks

- Thinking and Communicating With Clarity and Precision

- Thinking Flexibly

- Thinking Interdependently

Each Habit of Mind includes intelligent behaviors that are expected to be in action when a specific disposition is displayed. For example, if a person has the Habit to Think
Flexibly, that person displays the intelligent behaviors of changing perspective, generating alternatives, and considering a variety of options.

A Habit of Mind means having a disposition toward behaving intelligently when confronted with a problem to which the answer is not known (Costa, 1991). Behaving intelligently refers to problem-solving behavior that is constructed by experience gained through social interactions (Dewey, 1933). Intelligent behaviors are the external outcomes of the interaction between our cognition and emotions; they are what we can observe unlike neurological processes (Perez-Alvarez \& Timoneda-Gallart, 2007). These behaviors may provide clues about one's cognitive processes and functioning, skills, strategies, and one's disposition (Diez, 2006; Mullin, 2003).

Sometimes these behaviors are self-evident and observable, but in other cases, one needs to inquire into these behaviors as they may include cognitive processes that are not directly observable (Burant, Chubbuck, \& Whipp, 2007). Burant et al. (2007) state that "common sense and experience tell us that behavior can accurately be described as frequently, if not always, flowing congruently from interior values, dispositions, and moral convictions" (p. 402). They acknowledge that the relation between dispositions and behaviors are complex and that "this complexity, then calls for a more nuanced analysis" (p. 402). This call supports the need for a framework to guide the analysis of the relation between dispositions and behaviors.

\section{Method}

The main aim of this article is to investigate how best to cluster habits of mind when considering teacher dispositions. The authors were considering Costa and Kallick's model of Habits of Mind and wanted to better relate them to educational theories. The authors applied qualitative content analysis method to review the literature related to educational theories and Habits of Mind. The directed approach to content analysis (Hsieh \& Shannon, 2005), also called deductive category assignment (Mayring, 2014), entails identifying categories prior to the analysis and using predetermined codes or key concepts to assign the reviewed text to the categories. For the current study, the categories used were educational theories and the codes were the intelligent behaviors associated with Habits of Mind. A research committee that was comprised of the three authors of the article, an expert in the field of teacher education, and an educational psychologist were involved in the process of relating 16 Habits of Mind to educational theories, which resulted in constructing a conceptual framework. This process used an iterative approach that provided opportunities for the research committee to review, evaluate, and refine the outcomes (Figure 1).

The first step of the content analysis was to identify the potential educational theories that could be associated with Habits of Mind. But which habits fit best with which 


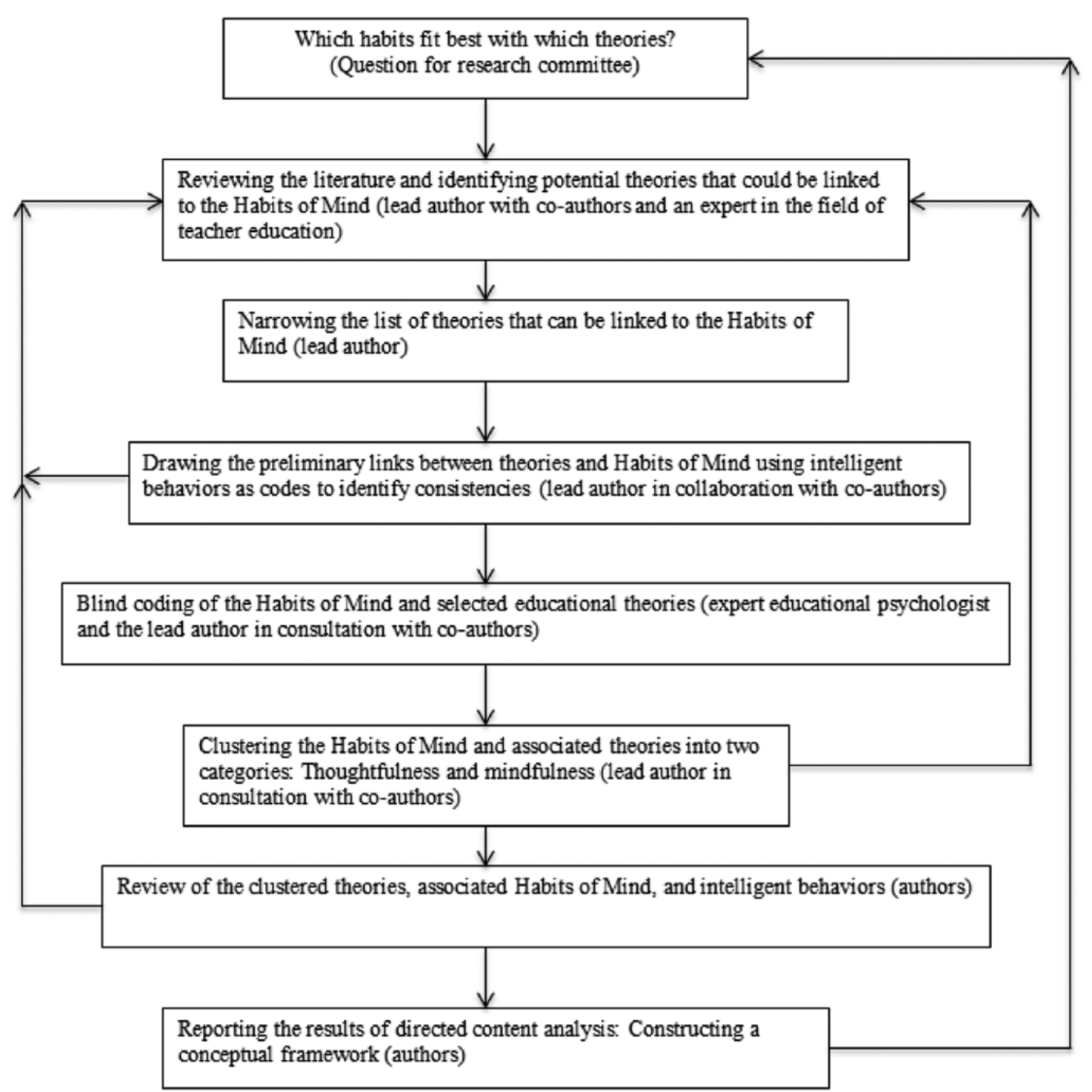

Figure I. The qualitative content analysis process to construct the conceptual framework.

theories? Therefore, the authors needed to gain a better understanding of the theories related to effective teaching dispositions in general and 16 Habits of Mind in particular. Although there are many educational theories that could be related, the authors decided to focus on the ones that would assist teacher educators in helping preservice teachers develop effective teaching dispositions. Through a review of the literature and consulting with an expert in the field of education, the authors chose the following theories as our categories: Constructivism, Incremental Theory, SelfRegulated Learning Theory, Mindfulness, and Emotional Intelligence.

The next step was to get a better understanding of the codes we planned to use to relate Habits of Mind to the theories. The lead author in collaboration with co-authors unpacked the intelligent behaviors associated with Costa and Kallick's model (2000) and used them as a common denominator to cluster the educational theories and construct a conceptual framework. A common denominator is defined as "something (such as a feature or quality) that is shared by all members of a group or things" and "a common trait or theme" (Merriam-Webster).

These common denominators served as our codes to help us identify consistencies between Habits of Mind and educational theories (Patton, 2002). As consistencies emerged, the intelligent behaviors, which were previously clustered under certain Habits of Mind by Costa and Kallick (2000), were re-grouped under associated theories. For example, one of the Habits of Mind, Persisting, includes the following two intelligent behaviors: having a repertoire of alternative 

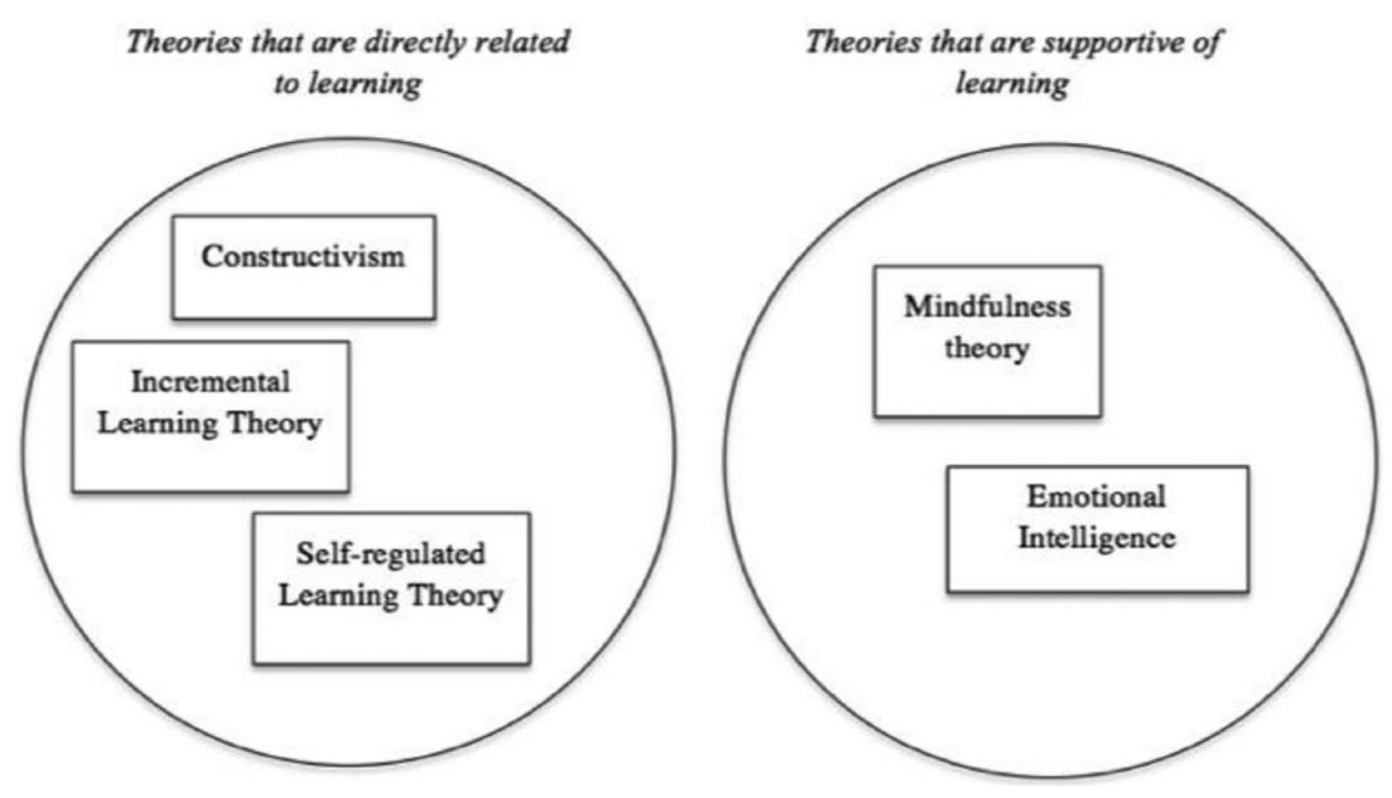

Figure 2. A model displaying theories relevant to thoughtfulness and mindfulness.

strategies for problem solving and employing a whole range of these strategies and not giving up easily. Based on the findings of our content analysis, we decided to place the first behavior under Self-Regulated Learning Theory and the second under Incremental Theory.

Hsieh and Shannon (2005) caution that with the directed content analysis approach, there is a chance for researcher bias. Therefore, as we were making these re-constructions, we consulted with an expert educational psychologist knowledgeable with these theories to confirm our associations (see "Acknowledgement" section). The lead author conducted a blind coding process with this expert educational psychologist. During this process, the associations between Habits of Mind and educational theories were made separately by each coder using the intelligent behaviors as common denominators. After the blind coding process, the lead author and educational psychologist compared their findings to see how they coded the associations. The initial agreement level between the lead author and the educational psychologist was high (87\%). The coders met and referred to the relevant literature to resolve the differences. After the meeting, there was full agreement. Subsequently, all final associations were confirmed by the co-authors.

Once the authors had an understanding of how Habits of Mind, educational theories, and intelligent behaviors are interrelated, they could develop the conceptual framework. A logical start to the grouping the theories was found in the work the of one of the co-authors (Dottin, 2009) and his discussion of the importance of thoughtfulness and mindfulness to make professional conduct more intelligent. To Dottin, mindfulness and thoughtfulness help to ground pedagogical dispositions as habits of pedagogical mindfulness and thoughtfulness (reflective capacity) that render professional actions and conduct more intelligent. According to Dottin, pedagogues must demonstrate commitments to patterns of intellectual activity that guide their cognitive and social behavior. As we acquire our habits through doing, undergoing the consequences of our doing, and making changes, the process is better enhanced through thinking and reflection that engenders intelligent action. The basis of intelligent action is framed by thoughtfulness that is geared more toward action that is guided by good reasoning, and mindfulness toward awareness, awareness in the sense of one foreseeing the end result of an act. Mindfulness and thoughtfulness, to Dottin, are key factors in acting intelligently, for to get results without intelligent control of means is to forego intelligent inquiry and intelligently controlled habit (Dewey, 1922).

Therefore, the authors used our literature review to decide which theories were more thoughtful (directly related to learning) and which more mindful (supportive of learning). Our analysis resulted in grouping Constructivism, Incremental Theory, and Self-Regulated Learning Theory together as theories directly related to learning, and identifying Mindfulness and Emotional Intelligence as theories that are supportive of learning processes (see Figure 2).

After forming these two groups, the directed content analysis was used to deduct which intelligent behaviors and associated Habits of Mind were directly related to learning and which were supportive of learning. Some of the intelligent behaviors, and subsequently the Habits of Mind, are associated with more than one theory. The next section shares the results of the content analysis, including a discussion of the 
interconnections and how the framework goes beyond cognitive traits and includes emotional and mindful traits as well.

\section{Educational Theories and Intelligent Behaviors That Are More Directly Related to Learning}

Constructivism and associated intelligent behaviors. Constructivism as a learning and meaning making theory focuses on the construction of knowledge and meaning by individuals (Ültanır, 2012). "The central principles of [constructivism are] that learners can only make sense of new situations in terms of their existing understanding. Learning involves an active process in which learners construct meaning by linking new ideas with their existing knowledge" (Naylor \& Keogh, 1999, p. 93). In Experience and Education (1938), Dewey focuses on ways of learning and he discusses the type of experiences through which learners can construct knowledge and understanding. According to Dewey, experience related to continuity and interaction is necessary for individuals to learn. Continuity of experiences refers to the experiential continuum through which individuals reflect on prior experiences, build on them, and develop habits that will be used in future experiences. Interaction of experiences between learners and their social environment helps to develop habits.

Piaget claims that knowledge is acquired as a result of modifying existing structures to fit the new data or situation through assimilation and accommodation (Bodner, 1986). For Piaget, acquisition of knowledge is a lifelong process through which we re-structure and modify our experiences based on the existing schemes in our minds to expand these existing schemes to accommodate the new knowledge or situation. Therefore, learning becomes meaningful only if the new knowledge is relevant to the existing schemes (Bodner, 1986).

Like Piaget, Vygotsky claims that individuals create knowledge that is built upon the existing knowledge and that is relevant to existing knowledge (Powell \& Kalina, 2009). Vygotsky focuses more on the social aspects of the mind when constructing the knowledge. Vygotsky stresses the importance of language development and collaboration when learning (Powell \& Kalina, 2009). Within the teaching context, some students may grasp concepts more quickly compared with others and some may struggle during the tasks. Vygotsky draws our attention to the importance of clarity in language as learning occurs when there is clarity (Powell \& Kalina, 2009). In a similar case, some students may seek help from others (e.g., peers or teachers) to assist their learning. Teachers who use a constructivist approach are likely to create a community of collaboration in the classroom that may provide opportunities for learners to interact more and develop thinking dispositions (Da RosVoseles \& Fowler-Haughey, 2007). Therefore, educators need to be introduced to key competencies related to Constructivism and provided opportunities to practice the behaviors that would help them apply strategies to enhance construction of knowledge.

In constructivism, there is an emphasis on modeling new behaviors through careful observation (Bandura, 1977), working in teams (Coppen, 2002), building upon prior experience and knowledge, transferring the prior knowledge to novel situations, questioning and inquiring, collaborating with others and use of language as a means of communication, and gathering data using a variety of sources especially sources from real life. The importance of the application of past knowledge to new situations, cooperative learning, developing and using mental maps, inquiring, and clarity in communication are highlighted through specified intelligent behaviors and Habits of Mind (see Table 1). Monitoring how preservice teachers exhibit these intelligent behaviors can give teacher educators insights into the development of competencies associated with constructivism.

Incremental Theory (growth mind-set) and associated intelligent behaviors. Related to constructivism is the idea that our intelligence can change and grow. Dewey (1938) states that education is life itself and therefore should remain open to continuous growth. This process of evolving knowledge relates to the notion of incremental learners as described in the Theory of Entity and Incremental Learners by Yeager and Dweck (2012). Seeing positive attitudes and perceptions about learning as the key dimension for successful learning holds significance for Dweck's $(1986,2000)$ Theory of Entity and Incremental Learners. Researchers in support of Incremental Theory believe that learners attain a growth mind-set and that intelligence is malleable and can evolve. Incremental learners are motivated to increase their knowledge and abilities by approaching challenging situations with persistence and a desire to learn. They see challenges as opportunities to grow (Dweck, 2016).

Incremental learning is in contrast to entity learners who believe that intelligence is fixed and nonchanging. Entity learners are motivated by successful displays of ability and attaining favorable judgments. They may quit when problems prove difficult and assume they are not smart enough. Mind-sets can shape social success at school as well as academic success, and this is promising for educators and parents. Furthermore, there has been a growing body of research demonstrating that growth mind-set behaviors can help thwart depression and aggression and help increase power and creativity (Dweck, 2016). As intellectual ability beliefs have roots in parenting and education, this means it is important to appreciate that a fixed mind-set can be reset (Dweck, 2016). Research has shown that positive attitudes and perceptions about learning are key for successful learning and that both teacher and student motivation may affect student achievement (Haimovitz, Wormington, \& Corpus, 2011). Furthermore, modeling positive perceptions and attitudes toward learning may impact students' construction of 
Table I. Habits of Mind and Intelligent Behaviors Related to Constructivism.

\begin{tabular}{|c|c|}
\hline Habits of mind & Intelligent behaviors \\
\hline Applying Past Knowledge to New Situations & $\begin{array}{l}\text { Accessing prior knowledge and work to transfer knowledge beyond the situation in } \\
\text { which it was learned } \\
\text { Calling upon one's store of knowledge and experience as sources of data to solve } \\
\text { each new challenge } \\
\text { Abstracting meaning from one experience, carrying it forth, and applying it in a novel } \\
\text { situation }\end{array}$ \\
\hline Creating, Imagining and Innovating & $\begin{array}{l}\text { Generating new and novel ideas, fluency, and originality } \\
\text { Seeking feedback from others to refine their techniques }\end{array}$ \\
\hline Gathering Data Through All Senses & Paying attention to the world around and gathering data through all of the senses \\
\hline Metacognition (Thinking About Thinking) & $\begin{array}{l}\text { Reflecting on experiences } \\
\text { Developing and using mental maps } \\
\text { Increasingly aware of one's actions on others }\end{array}$ \\
\hline Questioning and Posing Problems & $\begin{array}{l}\text { Developing questioning strategies to produce data } \\
\text { Asking questions that make causal connections and relationships }\end{array}$ \\
\hline Remaining Open to Continuous Learning & Continuously searching for new and better ways \\
\hline Taking Responsible Risks & Drawing on past knowledge, being thoughtful about consequences \\
\hline $\begin{array}{l}\text { Thinking and Communicating With Clarity and } \\
\text { Precision }\end{array}$ & Striving for accurate communication in both written and oral form \\
\hline Thinking Flexibly & $\begin{array}{l}\text { Changing one's perspective and generating alternatives as well as considering a } \\
\text { variety of options }\end{array}$ \\
\hline Thinking Interdependently & Being able to work with and learn from others \\
\hline
\end{tabular}

Source. Costa and Kallick (2000).

Table 2. Habits of Mind and Intelligent Behaviors Related to Incremental Theory.

\begin{tabular}{|c|c|}
\hline Habits of mind & Intelligent behaviors \\
\hline Persisting & $\begin{array}{l}\text { Remaining focused on tasks and looking for ways to reach a goal even when one is stuck } \\
\text { Not giving up easily } \\
\text { Persevering in tasks through to completion }\end{array}$ \\
\hline Remaining Open to Continuous Learning & $\begin{array}{l}\text { Continuously searching for new and better ways } \\
\text { Being eager to learn throughout lifetime } \\
\text { Striving for improvement, growing, learning, modifying, and improving oneself }\end{array}$ \\
\hline Responding With Wonderment and Awe & $\begin{array}{l}\text { Enjoying the challenge of problem solving and continuing to learn throughout their lifetimes } \\
\text { Being curious about ordinary things }\end{array}$ \\
\hline Striving for Accuracy & $\begin{array}{l}\text { Striving to always do one's best } \\
\text { Checking for ways to improve constantly }\end{array}$ \\
\hline Taking Responsible Risks & $\begin{array}{l}\text { Accepting confusion, uncertainty, and the higher risks of failure as part of the normal } \\
\text { process } \\
\text { Accepting setbacks as challenging and growth producing }\end{array}$ \\
\hline
\end{tabular}

Source. Costa and Kallick (2000).

their own perceptions and attitudes (Rattan, Good, \& Dweck, 2012).

Costa and Kallick (2008) suggest that successful learners constantly look for ways to improve and see challenges as opportunities to learn, they have high expectations of themselves, they are eager to learn throughout their lives, and they strive for improvement, growing, learning, and improving themselves. These intelligent behaviors find their places in Dweck's Incremental Theory (Growth Mind-Set). Teacher educators can look for these intelligent behaviors associated with Incremental Theory to help understand if their preservice teachers are developing dispositions that support an incremental view of intelligence (see Table 2).

Self-Regulated Learning Theory and associated intelligent behaviors. In an era of technological distractions, self-regulated learning is becoming more important. Self-regulation implies learners monitor and govern their own learning. They resist being distracted and reactive to external motivations. It involves understanding and controlling learning environments (Schunk, 1996). The ability for self-regulation can be a predictor of students' success in school as learners find a 
Table 3. Habits of Mind and Intelligent Behaviors Related to Self-Regulated Learning Theory.

\begin{tabular}{|c|c|}
\hline Habits of mind & Intelligent behaviors \\
\hline Applying Past Knowledge to New Situations & $\begin{array}{l}\text { Accessing prior knowledge and work to transfer knowledge beyond the situation in } \\
\text { which it was learned } \\
\text { Calling upon one's store of knowledge and experience as sources of data to solve each } \\
\text { new challenge } \\
\text { Abstracting meaning from one experience, carrying it forth, and applying it in a novel } \\
\text { situation }\end{array}$ \\
\hline Creating, Imagining, and Innovating & $\begin{array}{l}\text { Conceiving problem solutions differently, examining alternative possibilities from many } \\
\text { angles }\end{array}$ \\
\hline Gathering Data Through All Senses & Being aware of the pathways for gathering data and making use of a variety of sources \\
\hline Managing Impulsivity & $\begin{array}{l}\text { Intentionally establishing a vision of a product, action plan, goal, or destination before } \\
\text { acting } \\
\text { Developing a strategy for approaching a problem } \\
\text { Taking time and thinking before acting } \\
\text { Remaining calm, thoughtful, and reflective }\end{array}$ \\
\hline Metacognition (Thinking About Thinking) & $\begin{array}{l}\text { Developing a plan of action, maintaining that plan in mind over a period of time, then } \\
\text { reflecting on and evaluating the plan upon its completion } \\
\text { Reflecting on and evaluating the quality of skills and strategies } \\
\text { Reflecting on experiences } \\
\text { Developing an action plan based on reflection } \\
\text { Being aware of one's own thoughts, feelings, and actions and their effects on others }\end{array}$ \\
\hline Persisting & $\begin{array}{l}\text { Remaining focused on tasks and look for ways to reach a goal even when one is stuck } \\
\text { Having a repertoire of alternative strategies for problem solving, and employing a } \\
\text { whole range of these strategies } \\
\text { Collecting evidence to indicate if the problem-solving strategy is working, and if one } \\
\text { strategy doesn't work, knowing how to back up and try another } \\
\text { Persevering in tasks through to completion }\end{array}$ \\
\hline Questioning and Posing Problems & $\begin{array}{l}\text { Developing questioning strategies to produce data } \\
\text { Asking questions that make causal connections and relationships }\end{array}$ \\
\hline Taking Responsible Risks & Drawing on past knowledge, being thoughtful about consequences \\
\hline
\end{tabular}

Source. Costa and Kallick (2000).

way to succeed even in the cases of obstacles, poor study conditions, demotivating teachers, or unclear texts (Zimmerman, 1990, 1994). Self-regulation includes setting goals, managing time, applying learning strategies, conducting self-evaluation, seeking support, fostering intrinsic motivation, and developing self-efficacy (Zimmerman, 2002).

To become self-regulated learners, students need to develop intelligent behaviors that support monitoring their education (see Table 3). Zimmerman (2002) asserts that self-regulated learning strategies "can be learned from instruction and modeling by parents, teachers, coaches, and peers. In fact, self-regulated learners seek out help from others to improve their learning" (p. 6). Florez (2011) points out that teachers can model strategies to monitor one's learning. For example, they can show how planning results in positive outcomes and reduces anxiety. Persisting in complex situations and not giving up is another strategy that can be modeled and taught by teachers. Persisting through challenging tasks can help learners regulate their anxiety and teachers can show how they persist in the face of challenges. "Teaching children self-regulation first requires strong teacher self-regulation. Children learn to regulate thoughts, feeling, behavior and emotion by watching and responding to adults' self-regulation" (Florez, 2011, p. 6). Thus, teachers' understanding and modeling of self-regulation skills play an important role for encouraging students to learn and practice self-regulation skills.

Schraw, Crippen, and Hartley (2006) suggest that these strategies may help individuals understand and control their learning environment and help them plan, monitor, and evaluate their own learning. In other words, they will develop ways of thinking that help them regulate and monitor their own learning.

Individuals can improve their self-regulatory processes by setting goals, selecting appropriate strategies to achieve our purposes, implementing those strategies, and monitoring progress (Schunk \& Zimmerman, 1998; Schunk, 1996). Marzano (1992) and Costa and Kallick (2000) suggest that habits of mind can help learners to regulate their own learning processes. By focusing on intelligent behaviors that are associated with Self-Regulated Learning Theory, teacher educators can use these behaviors as strategies to observe, cultivate, and assess preservice teachers' selfregulation skills. 


\section{Intelligent Behaviors and Theories Supportive of Learning}

For our analysis of the association between intelligent behaviors and educational theories that are supportive of learning, we have turned to two established theories: Mindfulness and Emotional Intelligence. Given the many pressures and conflicts students face throughout the school day and in their lives, it is important for teachers to provide students with positive learning environments. Several of Costa and Kallick's Habits of Mind include intelligent behaviors that have affective attributes. These behaviors involve the development of emotional and psychological well-being when faced with problems. The theories of mindfulness and emotional intelligence serve to further understand these behaviors.

Mindfulness and associated intelligent behaviors. A number of theorists and researchers have explained what is meant by mindfulness. Kabat-Zinn (2003) defines mindfulness as "paying attention on purpose, [being] in the present moment, and non-judgmentally ... unfolding [the] experience moment by moment" (p. 144). The idea is for individuals to be aware and conscious of their thinking processes. Langer (2000) defines mindfulness as a "flexible state of mind in which we are actively engaged in the present, noticing new things and sensitive to context" (p. 220). Langer's definition of mindfulness as a construct includes five components: (a) openness to novelty; (b) alertness to distinction; (c) sensitivity to different contexts; (d) awareness of multiple perspectives; and (e) orientation in the present. Being in the present and aware of what is happening around us is important to keep our minds active. Hoyt (2016) defines mindfulness as

the energy of attention. It is the capacity in each of us to be present one hundred percent to what is happening within and around us. It is the miracle that allows us to become fully alive in each moment. (p. 29)

All three definitions hold implications for the benefits of practicing mindfulness in educational settings such as thinking before acting, giving thinking time for students before they rush in for the answers and solutions, and paying full attention (Hoyt, 2016).

Mindfulness is relatively new to K-12 education; however, teacher professional programs in many countries offer mindfulness training. Roeser, Skinner, Beers, and Jennings (2012) have created Mindfulness Training programs for teachers to develop habits of mind related to awareness of one's thinking processes. They suggest that helping teachers be more mindful improves their health and well-being; they learn how to create positive learning environments for their students. Mindfulness practice is offered as a strategy to help increase the cognitive, social, and psychological well-being of teachers and students (Meiklejohn et al., 2012). Broderick and Frank (2014) consider sustained and structured mindfulness programs fundamental for educators to support learners' cognitive skills for learning and their capacity for distress tolerance. As schools are places where students spend most of their time, in-school mindfulness practices may help students enhance their emotional competence and manage negative emotions. Broderick and Metz (2009) suggest that sustained and structured mindfulness programs (e.g., learning2breathe.org) may help reduce negative feelings and increase calmness and relaxation. Mindfulness practices can also help students become more aware of their own feelings and manage negative emotions. Therefore, they suggest that educators should be knowledgeable about cognitive and emotional developmental processes.

Table 4 identifies intelligent behaviors associated with Mindfulness Theory. The findings from Mindfulness research and related intelligent behaviors can provide strategies to support the development of mindfulness skills. Teacher educators can use reflective journaling and the arts to encourage preservice teachers to pay attention to the world around them: to gather data using all senses, take time before acting, remain calm, reflective, enjoy life, and the surrounding beauty (Costa \& Kallick, 2000).

Emotional Intelligence and associated intelligent behaviors. Finally, there are intelligent behaviors associated with emotions and thinking. According to Mayer, Salovey, and Caruso (2004), Emotional Intelligence "includes the abilities to accurately perceive emotions, to access and generate emotions so as to assist thought, to understand emotions and emotional knowledge, and to reflectively regulate emotions as to promote emotional and intellectual growth" (p. 197). Goleman's (1995) definition of emotional intelligence includes attributes such as empathy, impulse control, persistence, and delayed gratification. Ritchhart (2001) discusses the role of emotion before thought and how emotions can direct our short- and long-term thoughts. When we encounter a situation that we can feel empathy for, then our emotions may guide us to do something about that situation.

Factors such as family, friends, marital relations, and life stress play a role in developing emotional intelligence. Ferro (1993) states "emotions cannot be separated from learning" (p. 29) and indicates the importance of teachers and education in developing students' emotional intelligence. Jennings and Greenberg (2009) provide a model of emotional intelligence that illustrates how teachers' social and emotional competence and well-being affect the classroom climate and students' social and emotional and academic outcomes. The increasing number of demands and stressors teachers face can influence their ways of thinking and their ability to manage emotions. Therefore, teacher education needs to address emotion in education more explicitly to help teachers improve their social and emotional competence (Hawkey, 2006; Mayer, Caruso, \& Salovey, 1999). 
Table 4. Habits of Mind and Intelligent Behaviors Related to Mindfulness Theory.

\begin{tabular}{ll}
\hline Habits of mind & \multicolumn{1}{c}{ Intelligent behaviors } \\
\hline Gathering Data Through All Senses & $\begin{array}{l}\text { Being aware of the pathways for gathering data and making use of a variety of sources } \\
\text { Paying attention to the world around and gathering data through all of the senses } \\
\text { Taking time and thinking before acting } \\
\text { Remanaing Impulsivity }\end{array}$ \\
Responding With Wonderment and Awe & $\begin{array}{l}\text { Finding the world as an awesome and mysterious entity } \\
\text { Being intrigued with phenomena and the surrounding beauty } \\
\text { Taking Responsible Risks }\end{array}$ \\
& $\begin{array}{l}\text { Accepting confusion, uncertainty, and the higher risks of failure as part of the normal } \\
\text { process } \\
\text { Not behaving impulsively }\end{array}$ \\
\hline
\end{tabular}

Source. Costa and Kallick (2000).

Table 5. Habits of Mind and Intelligent Behaviors Related to Emotional Intelligence.

\begin{tabular}{ll}
\hline Habits of mind & \multicolumn{1}{c}{ Intelligent behaviors } \\
\hline Finding Humor & Placing value on having sense of humor \\
& Appreciating and understanding others' humor \\
& Being able to laugh at situations and themselves \\
Gathering Data Through All Senses & Being aware of the pathways for gathering data and making use of a variety of sources \\
& Paying attention to the world around and gathering data through all of the senses \\
Listening With Understanding and Empathy & Gently attending to another person demonstrating an understanding of and empathy \\
& for an idea or feeling \\
Managing Impulsivity & Making an effort to perceive another's point of view and emotions \\
Persisting & Remaining calm, thoughtful, and reflective \\
Taking Responsible Risks & Being comfortable with ambiguous situations \\
& Accepting confusion, uncertainty, and the higher risks of failure as part of the normal \\
& process \\
Thinking and Communicating With Clarity & Kot behaving impulsively \\
and Precision & Striving for accurate communication in both written and oral form \\
Thinking Flexibly & Considering alternative points of views \\
Thinking Interdependently & Tolerating ambiguity up to a point \\
& Being able to work with and learn from others \\
& Being sensitive to the needs of others
\end{tabular}

Source. Costa and Kallick (2000).

Teacher educators can use intelligent behaviors to identify strategies that help preservice teachers become socially and emotionally more competent (Goleman, 1995). For instance, teacher educators can place value on sense of humor and how it may contribute to supportive learning environments. Likewise, teacher educators can model these behaviors by gently attending to another person or remaining calm and not behaving impulsively. Intelligent behaviors related to emotional competence are listed in Table 5.

\section{Intelligent Behaviors Associated With More Than One Theory}

The above discussion explained how intelligent behaviors can be associated with selected educational theories. Based on our findings from a directed content analysis of the literature, we realized that some of these intelligent behaviors can be linked to more than one theory. For instance, the behavior of remaining calm, thoughtful and reflective under the Habit of Persisting can also be associated with SelfRegulated Learning Theory, Mindfulness, and Emotional Intelligence. An individual with self-regulated learning skills is expected to display the behavior of remaining thoughtful, an individual with mindfulness skills is expected to display the behavior of reflection, and an individual with emotional regulation skills is expected to display the state of remaining calm. Such an integrated approach to Habits of Mind is also discussed by Costa and Kallick (2000). They suggest that the habits can be clustered and in some cases they are not displayed in isolation. The findings of our analysis support such an argument. Table 6 shows only the common intelligent behaviors and with which theories they are associated. 
Table 6. Intelligent Behaviors That Are Associated With More Than One Theory.

\begin{tabular}{|c|c|c|c|c|c|c|}
\hline Habits of mind & Intelligent behaviors & C & $\mathrm{IT}$ & SRL & M & $\mathrm{El}$ \\
\hline \multirow[t]{3}{*}{$\begin{array}{l}\text { Applying Past Knowledge to } \\
\text { New Situations }\end{array}$} & $\begin{array}{l}\text { Accessing prior knowledge and work to transfer knowledge } \\
\text { beyond the situation in which it was learned }\end{array}$ & $\sqrt{ }$ & & $\sqrt{ }$ & & \\
\hline & $\begin{array}{l}\text { Calling upon one's store of knowledge and experience as } \\
\text { sources of data to solve each new challenge }\end{array}$ & $\sqrt{ }$ & & $\sqrt{ }$ & & \\
\hline & $\begin{array}{l}\text { Abstracting meaning from one experience, carrying it forth, } \\
\text { and applying it in a novel situation }\end{array}$ & $\sqrt{ }$ & & $\sqrt{ }$ & & \\
\hline \multirow[t]{2}{*}{$\begin{array}{l}\text { Gathering Data Through All } \\
\text { Senses }\end{array}$} & $\begin{array}{l}\text { Being aware of the pathways for gathering data and making } \\
\text { use of a variety of sources }\end{array}$ & & & $\sqrt{ }$ & $\sqrt{ }$ & $\sqrt{ }$ \\
\hline & $\begin{array}{l}\text { Paying attention to the world around and gathering data } \\
\text { through all of the senses }\end{array}$ & $\sqrt{ }$ & & & $\sqrt{ }$ & $\sqrt{ }$ \\
\hline \multirow[t]{2}{*}{ Managing Impulsivity } & Taking time and thinking before acting & & & $\sqrt{ }$ & $\sqrt{ }$ & \\
\hline & Remaining calm, thoughtful, and reflective & & & $\sqrt{ }$ & $\sqrt{ }$ & $\sqrt{ }$ \\
\hline Metacognition (Thinking & Reflecting on experiences & $\sqrt{ }$ & & $\sqrt{ }$ & & \\
\hline About Thinking) & $\begin{array}{l}\text { Being aware of one's own thoughts, feelings, and actions and } \\
\text { their effects on others }\end{array}$ & & & $\sqrt{ }$ & $\sqrt{ }$ & \\
\hline \multirow[t]{3}{*}{ Persisting } & $\begin{array}{l}\text { Remaining focused on tasks and look for ways to reach a } \\
\text { goal even when one is stuck }\end{array}$ & & $\sqrt{ }$ & $\sqrt{ }$ & & \\
\hline & Persevering in tasks through to completion & & $\sqrt{ }$ & $\sqrt{ }$ & & \\
\hline & Being comfortable with ambiguous situations & $\sqrt{ }$ & & & & $\sqrt{ }$ \\
\hline Questioning and Posing & Developing questioning strategies to produce data & $\sqrt{ }$ & & $\sqrt{ }$ & & \\
\hline Problems & $\begin{array}{l}\text { Asking questions that make causal connections and } \\
\text { relationships }\end{array}$ & $\sqrt{ }$ & & $\sqrt{ }$ & & \\
\hline \multirow[t]{3}{*}{ Taking Responsible Risks } & $\begin{array}{l}\text { Drawing on past knowledge, being thoughtful about } \\
\text { consequences }\end{array}$ & $\sqrt{ }$ & & $\sqrt{ }$ & & \\
\hline & $\begin{array}{l}\text { Accepting confusion, uncertainty, and the higher risks of } \\
\text { failure as part of the normal process }\end{array}$ & & $\sqrt{ }$ & & $\sqrt{ }$ & $\sqrt{ }$ \\
\hline & Not behaving impulsively & & & & $\sqrt{ }$ & $\sqrt{ }$ \\
\hline $\begin{array}{l}\text { Thinking and Communicating } \\
\text { With Clarity and Precision }\end{array}$ & $\begin{array}{l}\text { Striving for accurate communication in both written and } \\
\text { oral form }\end{array}$ & $\sqrt{ }$ & & & & $\sqrt{ }$ \\
\hline \multirow[t]{2}{*}{ Thinking Flexibly } & $\begin{array}{l}\text { Changing one's perspective and generating alternatives as } \\
\text { well as considering a variety of options }\end{array}$ & $\sqrt{ }$ & & $\sqrt{ }$ & & \\
\hline & Considering alternative points of views & & & $\sqrt{ }$ & & $\sqrt{ }$ \\
\hline Thinking Interdependently & Being able to work with and learn from others & $\sqrt{ }$ & & & & $\sqrt{ }$ \\
\hline
\end{tabular}

Source. Costa and Kallick (2000).

Note. $\mathrm{C}=$ Constructivism, IT = Incremental Theory, SRL = Self-Regulated Learning, $M=$ Mindfulness, El = Emotional Intelligence.

\section{Conclusion}

\section{Toward a Framework to Understand and Develop Effective Teaching Dispositions}

Dewey's work has helped scholars understand the construct of dispositions in teacher education. As the authors of this article, we have also turned back to Dewey's work to better identify dispositions and to learn in which contexts dispositions can be cultivated. Building upon Dewey's discussions on viewing dispositions as habits and using Nelsen's suggestion of viewing dispositions as cluster of habits, we have constructed a framework that encapsulates both ideas.

The conceptual framework (Figure 3) was developed through a content analysis of the literature related to dispositions and educational theories. The researchers linked Habits of Mind to specific educational theories using intelligent behaviors as common denominators. Teacher educators can use these intelligent behaviors as cues to understand how and why their students respond the way they do to different situations and settings. After using approaches such as interviews, long-term observation, deliberation, and inquiry into the underlying motivators for preservice teachers' actions, the behaviors can be linked to one of the clusters of habits (dispositions) identified in the model we introduce in this article.

As the clusters are now related to established theories, the findings from empirical research associated with those theories can be used by teacher educators to guide professional development of teaching dispositions. For example, research that supports Constructivism can be used to develop the Habit of Applying Past Knowledge to New Situations. The associated intelligent behaviors can be observed and measured to learn how the disposition is being developed. Likewise, research that supports Incremental Theory can be used to develop the Habit of Remaining Open to Continuous 


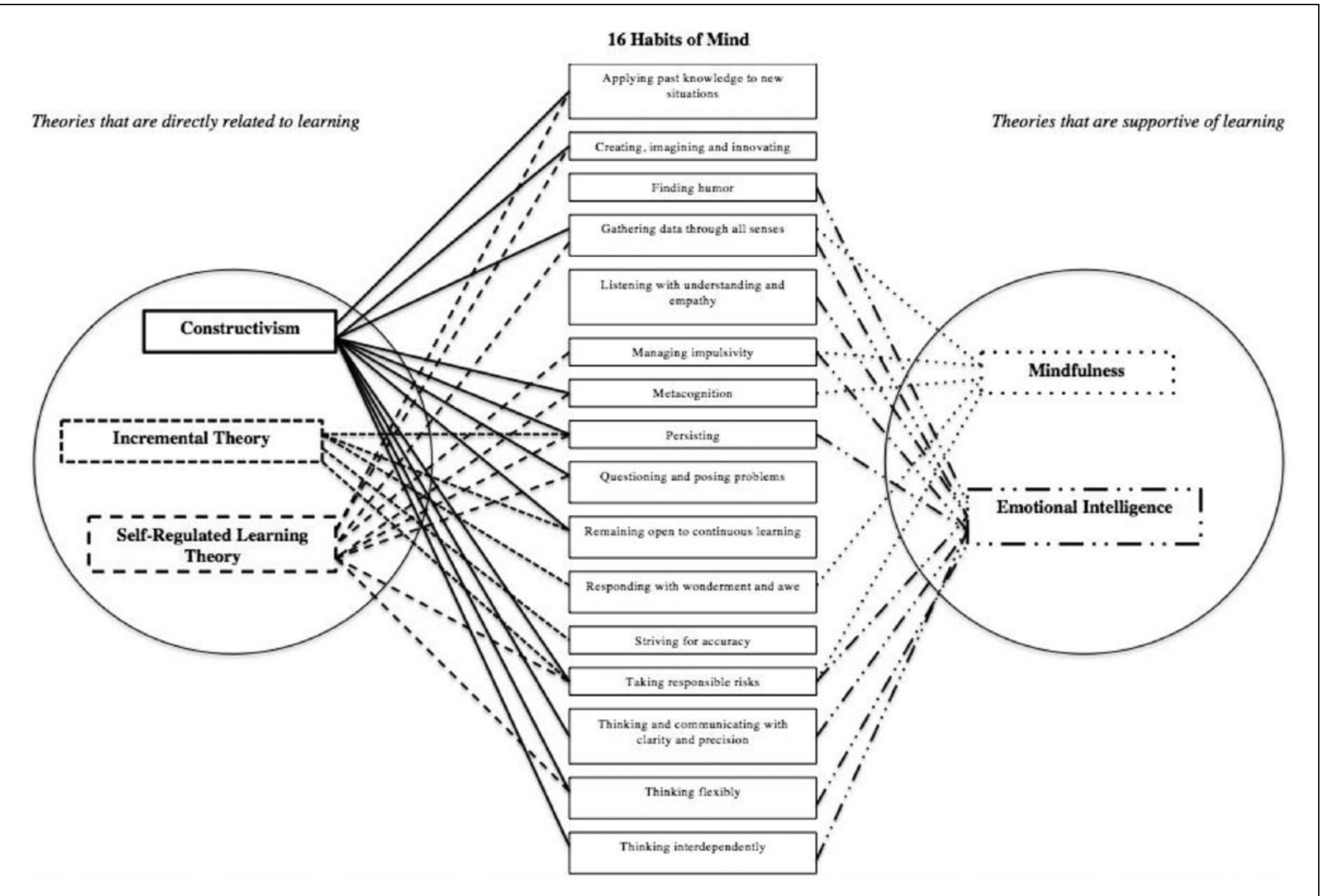

Figure 3. A conceptual framework that is developed based on intelligent behaviors from $16 \mathrm{Habits}$ of Mind and relevant established theories to better understand dispositions as clusters of habits in teacher education.

Learning. Preservice teachers who have this Habit of Mind will exhibit behaviors such as continuously searching for new and better ways and striving for improvement, growing, learning, modifying, and improving themselves. In another case, the teacher educator might need to develop students' Habit of Thinking About Thinking (Metacognition). In this case, teacher educator can look into Self-Regulated Learning Theory to help students develop the intelligent behaviors such as developing an action plan and being aware of one's own thoughts and their effects on others. Another situation might occur when a methods teacher notices that a candidate overreacts to challenges and conflicts. The teacher educator might also be concerned that the student makes quick judgments and is not reflective. This instructor could research into Mindfulness Theory to identify strategies to develop mindful behaviors associated with the Habit of Managing Impulsivity. A similar situation can be when a teacher educator might be concerned that students are not sensitive to the needs of others. Then, the educator could research into Emotional Intelligence theory to help students develop the Habit of Thinking Interdependently. Each of the 16 Habits proposed by Costa and Kallick could be addressed in this fashion. Our analysis indicates that by focusing on selected educational theories related to thoughtfulness and mindfulness, teacher educators may be able to help develop a wide range of Habits of Mind.

By associating intelligent behaviors with educational theories, we have offered a framework that teacher educators can use in teacher education programs to help develop preservice teachers' dispositions as Habits of Mind. We believe that this framework will help teacher education programs move forward in understanding and applying dispositions in teacher education: it offers clearly defined intelligent behaviors that can be developed using research from well-grounded educational theories. We anticipate scholars and teacher educators may investigate and suggest some intelligent behaviors may be associated with different theories (e.g., setting high standards and Perfectionism theories). Investigating into wellgrounded educational theories, such as the ones we used for developing the framework, can contribute to the understanding and application of dispositions in teacher education.

\section{Acknowledgment}

The authors express their sincere gratitude to Dr. Aikaterini Michou who provided insight and expertise that greatly assisted reviewing the conceptual framework. 


\section{Declaration of Conflicting Interests}

The author(s) declared no potential conflicts of interest with respect to the research, authorship, and/or publication of this article.

\section{Funding}

The author(s) received no financial support for the research, authorship, and/or publication of this article.

\section{References}

Bandura, A. (1977). Social Learning Theory. Englewood Cliffs, NJ: Prentice Hall.

Bandura, M., \& Dweck, C. S. (1985). The relationship of conceptions of intelligence and achievement goals to achievement-related cognition, affect, and behavior. Unpublished manuscript, Harvard University, Cambridge, MA.

Bercaw, L., Summers, D., Colby, S., \& Payne, M. (2012). Mirror images: Teacher candidates' perceptions of disposition development. Action in Teacher Education, 34(5/6), 514-525.

Bodner, G. M. (1986). Constructivism: A theory of knowledge. Journal of Chemical Education, 63(10), 873-878.

Borko, H., Liston, D., \& Whitcomb, J. (2007). Genres of empirical research in teacher education. Journal of Teacher Education, 58(1), 3-11.

Broderick, P. C., \& Frank, J. L. (2014). Learning to BREATHE: An intervention to foster mindfulness in adolescence. New Directions in Youth Development, 142, 31-44.

Broderick, P. C., \& Metz, S. (2009). Learning to BREATHE: A pilot trial of a mindfulness curriculum for adolescents. Advances in School Mental Health Promotion, 2, 35-46.

Burant, T. J., Chubbuck, S. M., \& Whipp, J. L. (2007). Reclaiming the moral in the dispositions debate. Journal of Teacher Education, 58(5), 397-411.

Caena, F. (2011). Teachers' core competences: Requirements and development-Literature review. European Commission, Directorate-General for Education and Culture. Retrieved from http://ec.europa.eu/dgs/education_culture/repository/education/policy/strategic-framework/doc/teacher-development_ en.pdf

Campbell, J. (2006, November). Theorising habits of mind as a framework for learning. Paper presented at Australian Association for Research in Education, Adelaide. Retrieved from http://aassaquito2012.pbworks.com/w/file/fetch/51873287/Theorising\%20 Habits\%20of\%20Mind\%20as\%20a\%20Framework\%20for\%20 Learning.pdf

Claxton, G., \& Carr, M. (2004). A framework for teaching learning: The dynamics of disposition. Early Years, 24(1), 87-97.

Coppen, M. (2002). New directions for tomorrow's schools: A personal view from New Zealand. PEB Exchange, 2(46), 22-24.

Costa, A. L. (1991). The search for intelligent life. In A. Costa (Ed.), Developing minds: A resource book for teaching thinking (pp. 100-106). Alexandria, VA: Association for Supervision and Curriculum Development.

Costa, A. L. (2001). Habits of mind. In A. Costa (Ed.), Developing minds: A resource book for teaching thinking (pp. 80-86). Alexandria, VA: Association for Supervision and Curriculum Development.

Costa, A. L., \& Kallick, B. (2000). Habits of mind. Alexandria, VA: Association for Supervision and Curriculum Development.
Costa, A. L., \& Kallick, B. (Eds.). (2008). Learning and leading with habits of mind: 16 essential characteristics for success. Alexandria, VA: Association for Supervision and Curriculum Development.

Costa, A. L., \& Kallick, B. (2014). Dispositions: Reframing teaching and learning. Thousand Oaks, CA: Corwin.

Council for the Accreditation of Educator Preparation. (2013). CAEP standards for accreditation of educator preparation. Retrieved from http://caepnet.org/standards/introduction

Da Ros-Voseles, D., \& Fowler-Haughey, S. (2007). Why children's dispositions should matter to all teachers. Beyond the Journal: Young Children on the Web, 1(3), 1-7.

Dewey, J. (1922). Human nature and conduct: An introduction to social psychology. New York, NY: Henry Holt.

Dewey, J. (1933). How we think: A restatement of the relation of reflective thinking to the educative process. Chicago, IL: Henry Regnery.

Dewey, J. (1938). Experience and education. New York, NY: Collier.

Diez, M. E. (2006). Assessing dispositions: Five principles to guide practice. In H. Sockett (Ed.), Teacher dispositions: Building a teacher education framework of moral standards (pp. 4968). Washington, DC: American Association of Colleges for Teacher Education.

Diez, M. E. (2007). Looking back and moving forward: Three tensions in the teacher dispositions discourse. Journal of Teacher Education, 58(5), 388-396.

Dottin, E. (2009). Professional judgment and dispositions in teacher education. Teaching and Teacher Education, 25, 83-88.

Dottin, E. S. (2010). Dispositions as habits of mind: Making professional conduct more intelligent. Lanham, MD: University Press of America.

Dottin, E. S., \& Sockett, H. (2006). A Deweyan approach to the development of moral dispositions in professional teacher education communities. In H. Sockett (Ed.), Teacher dispositions: Building a teacher education framework of moral standards (pp. 27-47). New York, NY: American Association of Colleges for Teacher Education.

Dweck, C. S. (1986). Motivational processes affecting learning. American Psychologist, 41(10), 1040-1048.

Dweck, C. S. (2000). Self-theories: Their role in motivation, personality, and development. Philedelphia, PA: Psychology Press.

Dweck, C. S. (2016). The remarkable reach of growth mind-sets. Scientific American Mind, 27(1), 36-41.

Ennis, R. H. (1996). Critical thinking dispositions: Their nature and assessability. Informal Logic, 18(2\&3), 165-182.

Facione, P. A., Sanchez, C. A., Facione, N. C., \& Gainen, J. (1995). The disposition toward critical thinking. Journal of General Education, 44(1), 1-25.

Ferro, R. T. (1993). The influence of affective processing in education and training. New Directions for Adult and Continuing Education, 59, 25-33.

Florez, R. I. (2011). Developing young children's self-regulation through everyday experiences. Young Children, 46-51.

Freeman, L. (2007). An overview of dispositions in teacher education. In M. E. Diez \& J. Raths (Eds.), Dispositions in teacher education (pp. 3-29). Charlotte, NC: Information Age Publishing.

Goleman, D. (1995). Emotional intelligence. New York, NY: Bantam Books. 
Haimovitz, K., Wormington, S. V., \& Corpus, J. H. (2011). Dangerous mindsets: How beliefs about intelligence predict motivational change. Learning and Individual Differences, 21, 747-752.

Hawkey, K. (2006). Emotional intelligence and mentoring in preservice teacher education: A literature review. Mentoring \& Tutoring, 14(2), 137-147.

Hoyt, M. (2016). Teaching with mindfulness: The pedagogy of being-with/for and without being-with/for. Journal of Curriculum Theorizing, 31(1), 126-142.

Hsieh, H.-F., \& Shannon, S. E. (2005). Three approaches to qualitative content analysis. Qualitative Health Research, 15(9), 1277-1288.

Interstate New Teacher Assessment and Support Consortium. (1992). Model standards for beginning teacher licensing, assessment and development: A resource for state dialogue. Retrieved from http://www.ccsso.org/content/pdfs/corestrd.pdf

Interstate New Teacher Assessment and Support Consortium. (2013). Model core teaching standards and learning progressions for teachers 1.0. Washington, DC: Council of Chief State School Officers.

Jennings, P. A., \& Greenberg, M. (2009). The prosocial classroom: Teacher social and emotional competence in relation to child and classroom outcomes. Review of Educational Research, 79, 491-525.

Kabat-Zinn, J. (2003). Mindfulness-based interventions in context: Past, present, and future. Clinical Psychology: Science \& Practice, 10(2), 144-156.

Katz, L. G. (1993). Dispositions: Definitions and implications for early childhood practice. Retrieved from http://files.eric. ed.gov/fulltext/ED360104.pdf

Katz, L. G., \& Raths, J. D. (1985). A framework for research on teacher education programs. Journal of Teacher Education, 36(6), 9-15.

Langer, E. J. (2000). Mindful learning. Current Directions in Psychological Science, 9(6), 220-223.

Marzano, R. J. (1992). A different kind of learning: Teaching with dimensions of learning. Alexandria, VA: Association for Supervision and Curriculum Development.

Mayer, J. D., Caruso, D. R., \& Salovey, P. (1999). Emotional intelligence meets traditional standards for an intelligence. Intelligence, 27(4), 267-298.

Mayer, J. D., Salovey, P., \& Caruso, D. R. (2004). Emotional intelligence: Theory, findings and implications. Psychological Inquiry, 60, 197-215.

Mayring, P. (2014). Qualitative content analysis: Theoretical foundations, basic procedures and software solution. Social Science Open Access Repository. Retrieved from http://nbn-resolving. de/urn:nbn:de:0168-ssoar-395173

Meiklejohn, J., Phillips, C., Freedman, M. L., Griffin, M. L., Biegel, G., Roach, A., . . . Saltzman, A. (2012). Integrating mindfulness training into K-12 education: Fostering resilience of teachers and students. Mindfulness, 3, 291-307.

Mullin, D. (2003, January). Developing a framework for the assessment of teacher candidate dispositions. Paper presented at the annual meeting of the American Association of Colleges for Teacher Education, New Orleans, LA.

National Council for Accreditation of Teacher Education. (2008). Professional standards for the accreditation of teacher preparation institutions. Retrieved from http://www.ncate.org/
Portals/0/documents/Standards/NCATE\%20Standards\%20 2008.pdf

Naylor, S., \& Keogh, B. (1999). Constructivism in classroom: Theory into practice. Journal of Science Teacher Education, 10, 93-106.

Nelsen, P. J. (2015). Intelligent dispositions: Dewey, habits and inquiry in teacher education. Journal of Teacher Education, 66(1), 86-97.

Patton, M. Q. (2002). Qualitative research and evaluation methods. Thousand Oaks, CA: SAGE.

Paul, R. W. (1990). Critical thinking: What every person needs to survive in a rapidly changing world. Rohnert Park, CA: Center for Critical Thinking and Moral Critique, Sonoma State University.

Perez-Alvarez, F., \& Timoneda-Gallart, C. (2007). A better look at intelligent behavior: Cognition and emotion. New York, NY: Nova Science Publishers.

Perkins, D., Jay, E., \& Tishman, S. (1993). Teaching thinking: From ontology to education. Educational Psychologist, 28(1), 67-85.

Powell, K. C., \& Kalina, C. J. (2009). Cognitive and social constructivism: Developing tools for an effective classroom. Education, 130(2), 241-250.

Rattan, A., Good, C., \& Dweck, C. S. (2012). "It's ok-Not everyone can be good at math": Instructors with an entity theory comfort (and demotivate) students. Journal of Experimental Social Psychology, 48, 731-737.

Ritchhart, R. (2001). From IQ to IC: A dispositional view of intelligence. Roeper Review, 23(3), 143-150.

Ritchhart, R. (2002). Intellectual character: What it is, why it matters, and how to get it. San Francisco, CA: Jossey-Bass.

Roeser, R. W., Skinner, E. A., Beers, J., \& Jennings, P. A. (2012). Mindfulness training and teachers' professional development: An emerging area of research and practice. Child Development Perspectives, 6, 146-153.

Ruitenberg, W. C. (2011). The trouble with dispositions: A critical examination of personal beliefs, professional commitments and actual conduct in teacher education. Ethics and Education, $6(1), 41-52$.

Schraw, G., Crippen, K., \& Hartley, K. (2006). Promoting self-regulation in science education: Metacognition as part of a broader perspective on learning. Research in Science Education, 36, 111-139.

Schunk, D. (1996). Goal and self-evaluative influences during children's cognitive skill learning. American Educational Research Journal, 33, 359-382.

Schunk, D. H., \& Zimmerman, B. J. (Eds.). (1998). Self-regulated learning: From teaching to self-reflective practice. New York, NY: The Guilford Press.

Serdyukov, P., \& Ferguson, B. T. (2011). Teacher dispositions: What kind of candidates do we have in a teacher education program and how do we make them better? Journal of Research in Innovative Teaching, 4(1), 106-119.

Thornton, H. (2006). Dispositions in action: Do dispositions make a difference in practice? Teacher Education Quarterly, 33(2), 53-68.

Ültanır, E. (2012). An epistemological glance at the constructivist approach: Constructivist learning in Dewey, Piaget, and Montessori. International Journal of Instruction, 5(2), 195-212.

Yeager, D. S., \& Dweck, S. C. (2012). Mindsets that promote resilience: When students believe that personal characteristics can be developed. Educational Psychologist, 47(4), 302-314. 
Zimmerman, B. J. (1990). Self-regulated learning and academic achievement: An overview. Educational Psychologist, 25(1), 3-17.

Zimmerman, B. J. (1994). Dimensions of academic self-regulation: A conceptual framework for education. In D. H. Schunk \& B. J. Zimmerman (Eds.), Self-regulation of learning and performance: Issues and educational applications (pp. 3-24). Hillsdale, NJ: Lawrence Erlbaum.

Zimmerman, B. J. (2002). Becoming a self-regulated learner: An overview. Theory Into Practice, 41, 64-72.

\section{Author Biographies}

Servet Altan received his $\mathrm{PhD}$ in curriculum and instruction from Bilkent University in June 2017. Currently, he is an International Education (IB MYP) coordinator for a private middle school in Ankara and a part-time instructor at Bilkent University, Graduate School of Education. He was awarded full scholarship by the U.S. Embassy Ankara for educational projects at Iowa State University and Indiana University. His current research areas include teacher education, educational theories, and habits of mind.

Jennie F. Lane is an assistant professor within the Graduate School of Education at Bilkent University. She received her $\mathrm{PhD}$ in curriculum and instruction from University of Wisconsin-Madison. Prior to coming to Bilkent, she was the director of the Wisconsin K-12 Energy Education Program (KEEP). Her other work experience includes co-authoring the Project WET Curriculum and
Activity Guide which is used throughout the world, teaching public school in New York City and Lewiston, Maine, and instructing preservice teachers in Thailand and at the University of WisconsinStevens Point. Her research areas include environmental, placebased, and sustainability education.

Erskine Dottin a Fulbright Scholar to Nigeria, received his $\mathrm{PhD}$ in education policy analysis at Miami University of Ohio, and is professor emeritus and Frost professor in the School of Education and Human Development at Florida International University. As Frost professor, he started the first ever Faculty Learning Community on Habits of Mind in the College and contributed to the college's decision to focus its teacher education program for preservice and inservice teacher dispositions as habits of mind. He is the author of Developing a Conceptual Framework: The Stimulation for Coherence and Continuous Improvement in Teacher Education; Creating a Professional Community Through Means-Ends Connections to Facilitate the Acquisition of Moral Dispositions: Developing, Living, and Evaluating a Conceptual Framework in Teacher Education; and Dispositions as Habits of Mind: Making Professional Conduct More Intelligent. He has co-authored Thinking About Education: Philosophical Issues and Perspectives; Teaching as Enhancing Human Effectiveness; Enhancing Effective Thinking and ProblemSolving in Teacher Education Candidates and In-Service Professional Educators; Bringing Out the Best in Human Effectiveness: Lessons for Educators From an Upward Bound Project; and Structuring Learning Environments in Teacher Education to Elicit Dispositions as Habits of Mind: Strategies Used and Lessons Learned. 